\title{
Prospective Randomized Study between Open Vs Closed Lateral Anal Internal Sphincterotomy in Patients with Chronic Fissure in Ano
}

\author{
Anand Shanmugaiah ${ }^{\circledR}$, Saravanan Pandian ${ }^{\circledR 2}$ \\ ${ }^{1}$ Assistant Professor Department of General Surgery, Indira Gandhi Medical College and Hospital, Kathirkamam, Puducherry, India, ${ }^{2}$ Assistant Professor, Department of \\ General Surgery, Indira Gandhi Medical College and Hospital, Kathirkamam, Puducherry, India.
}

\section{Abstract}

Background: One of the the most common cause of pain during defecationin young patientsis chronic fissure in ano. Surgical treatment of choice for chronic fissure in ano is internal sphincterotomy. This procedure can be performed by open or closed method. The aim of the study was to compare the closed and open anal internal sphincterotomy in patients admitted in our hospital with chronic anal fissure. Subjects and Methods: 105 patients admitted in department of general surgery with chronic fissure in ano were divided into two groups. 50 patients (Group A) who were treated by closed method and 55 patients (Group B) who were managed by open lateralanal sphincterotomy method. A 3 months follow up done in both post-surgery to observe for pain, bleeding, infection, incontinence, and recurrence. Results: Significant difference was observed in postoperative acute complications between the two methods of internal anal sphincterotomy. Conclusion: Lateral anal sphincterotomy is the treatment of choice for chronic anal fissure, either open or closed method. However, the closed method was observed to have lesserpost operative complication compared to the open method.

Keywords: Anal Fissure, Postoperative Complications, Sphincterotomy

Corresponding Author: Anand Shanmugaiah, Assistant Professor Department of General Surgery, Indira Gandhi Medical College and Hospital, Kathirkamam, Puducherry, India.

E-mail: anand29browsing@gmail.com

Received: 12 May 2020

Revised: 14 June 2020

Accepted: 25 June 2020

Published: 5 July 2020

\section{Introduction}

Fissure in ano is a painful condition of anoderm. Increased tone of internal anal spincter along with tissue hypoperfusion is the cause of development of chronic fissure in ano. ${ }^{[1,2]}$ Fissure in ano is divided into acute and chronic. Sentinel tag, hypertrophic anal papillae, anal spasm or fibrosis of the internal sphincter muscle are certain features of chronic fissure in ano. The common location of chronic fissure in anois 6 o' clock posteriorly and rarely at 12 o' clock anteriorly in recumbent position. Multiple fissures or fissure with fistula and fissures at other position needs further investigation. Crohn's disease, anal intercourse, sexually transmitted disease, or anal carcinoma are certain conditions which can present with multiple fissures in ano. ${ }^{[3]}$

Classical presentation includes severe burning/tearing pain during defecation that lasts for few hours afterwards. Bleeding per rectum usually mild may be present along with pain. The blood may stain the stool surface or it may be in the shape of drops after defecation; rarely, it may be severe. ${ }^{[4]}$
The fissure can be seen by gently parting the buttocks and everting the anal verge. Digital rectal examination and proctosigmoidoscopy are absolutely contraindicated in acute phase. ${ }^{[4]}$ Initial treatment of most cases is conservative with usage of bulking agents, stool softeners, local anesthesia creams, and sitz bath. In chronic fissure, conservative method may not be so effective. ${ }^{[4]}$ Topical glycerol trinitrate $0.2 \%$ ointment applied twice a day for weeks has proved to reducethe symptoms of chronic anal fissure. ${ }^{[5]}$

Lateral anal sphincterotomy (LAS) is the surgical treatment of choice in patients with chronic anal fissure where medical management fails. This procedure may be performed either by open or closed method. In LAS the lower third to half of the internal sphincter is divided thereby reducing the spasm and increasing local anoderm blood flow. ${ }^{[4]}$ Surgical sphincterotomyhas a high healing rate in patients with chronic fissure. By 6 weeks post operativeperiod, 94.7-96\% of fissures heal with a low recurrence rate. ${ }^{[5-7]} 5$ years failure rates is seen in $2-3 \%{ }^{[8]}$

\section{Aims and Objectives}


The aim of this study is to compare closed vs open lateral internal anal sphinterotomy in patients with chronic fissure in Ano.

\section{Subjects and Methods}

\section{Types of Intervention}

a. Closed lateral internal anal sphinterotomy.

b. Open lateral internal anal sphinterotomy.

\section{Types of Outcome Measures}

- Pain on the first post-operative day.

- Pain at one month follows up.

- Post-operative Bleeding per rectum

- Local infection

- Incontinence

- Recurrence

\section{Inclusion Criteria}

a. Patients of any age.

b. Patients having chronic fissure in ANO.

c. Patient willing to give informed consent.

\section{Exclusion Criteria}

a. patients with associated haemorrhoids, fistula , multiple fissures

b. Patient unfit for surgery under general anaesthesia.

\section{Sample Size}

Number of patients to be studied are 105. Statistical Analysis of my study will be by standard- ' $\mathrm{t}$ ' test, chi-square method.

This study was a prospective randomized study on 105 patients with chronic fissure in an admitted for surgery to Indira Gandhi medical college and Hospital puduchery from June 2018 to December 2018. Patients were divided into two groups based on odd and even admissions. Group A with 50 patients were subjected to closed LAS and Group B with 55 patients were subjected to open LAS.

Routine investigations and preoperative assessment done in all patients. Both procedures were performed under spinal anaesthesia.

In closed method, patient put in lithotomy position after spinal anaesthesia, internal sphincter was palpated by the left index finger by inserting into anal canal. The intersphinteric groove was felt and a $1 \mathrm{~cm}$ incision made in the groove and the scalpel was used to divide the lower third of internal sphincter controlled by the left index finger. In open method, anal canal was retracted
In the open method, anal canal was retracted using park retractor and intersphincteric groove is felt. 1-cm incision was made in the intersphinc tericgroove and an artery forceps was used to separate the muscle from the mucosa and the lower third is divided followed by pressure for $3 \mathrm{~min}$ to control bleeding. This was followed by closure of the wound with Vicryl 4/0 suture. Sterile dressing applied after the procedure. Pain, bleeding, infection, incontinence, and recurrence were observed in both groups of patients over a 3 months period. Statistical analysis Data were analyzed using a computer SPSS program, version 18 (Developers: IBM Corporation, University of Chicago). Fisher test and Student's test were used for statistical analysis.

\section{Results}

105 patients with chronic fissure in ano were taken up for study at the Indira Gandhi medical college and Hospitals, puducherry during the period of June 2018 and December 2018. Those cases were admitted to the Department of Surgery and following were observed.

Below 25 years there were 15 females and 5 male, between 25 - 35 years there were 38 females and 16 males, between 35 - 45 years there were 20 females and 11 males. In this study, the peak incidence of chronic fissure in ano was between 25 - 35 years. Out of 105 cases under study $30 \%$ are males and $70 \%$ are females, incidence of 1:2.3 (M:F) showing female predominance.

\begin{tabular}{|c|c|c|c|c|c|c|}
\hline $\begin{array}{l}\text { Age } \\
\text { in } \\
\text { yrs }\end{array}$ & Male & $\%$ & Femalı & $\%$ & Total & $\%$ \\
\hline $\begin{array}{l}<25 \\
\text { years }\end{array}$ & 5 & $16.39 \%$ & 15 & $20.83 \%$ & 20 & $19.51 \%$ \\
\hline $\begin{array}{l}25- \\
35 \text { year }\end{array}$ & 16 & $49.18 \%$ & 38 & $51.38 \%$ & 54 & $50.73 \%$ \\
\hline $\begin{array}{l}35- \\
45 y e a r\end{array}$ & 11 & $34.42 \%$ & 20 & $27.77 \%$ & 31 & $29.75 \%$ \\
\hline Total & 32 & $100 \%$ & 73 & $100 \%$ & 105 & $100 \%$ \\
\hline
\end{tabular}

Out of 105 cases 50 cases underwent closed lateral anal sphincterotomy (group A) and 55 cases underwent open lateral anal sphincterotomy (group B).

65 patients presented with pain during defecation alone and 40 patients presented with pain during defecation along with bleeding.

On examination, 84 patients had fissure at posterior location and 19 patients had at anterior location. 2 patients had fissure both anterior and posterior location. 


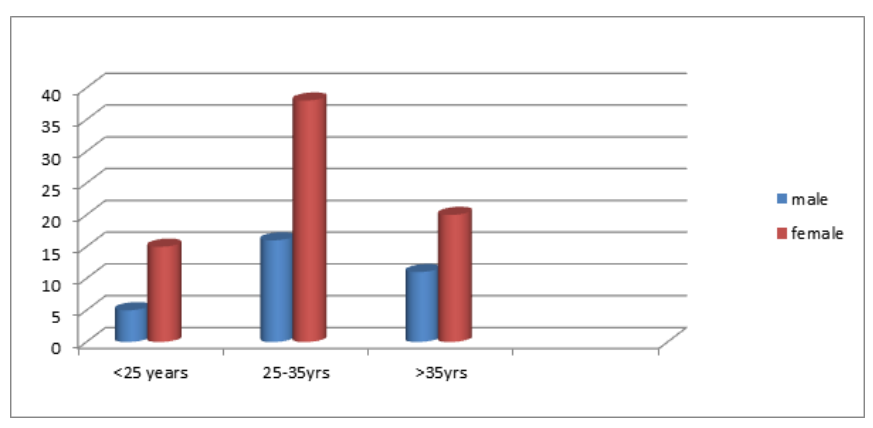

Figure 1: Gender Distribution

\begin{tabular}{|c|c|c|}
\hline $\begin{array}{l}\text { Type of proce- } \\
\text { dure }\end{array}$ & $\begin{array}{l}\text { Number of } \\
\text { patients }\end{array}$ & Percentage \\
\hline $\begin{array}{l}\text { closed lateral } \\
\text { internal anal } \\
\text { sphincterotomy }\end{array}$ & 50 & $47.8 \%$ \\
\hline $\begin{array}{lr}\text { open lateral } \\
\text { internal anal } \\
\text { sphincterotomy }\end{array}$ & 55 & $52.2 \%$ \\
\hline Total & 105 & $100 \%$ \\
\hline
\end{tabular}

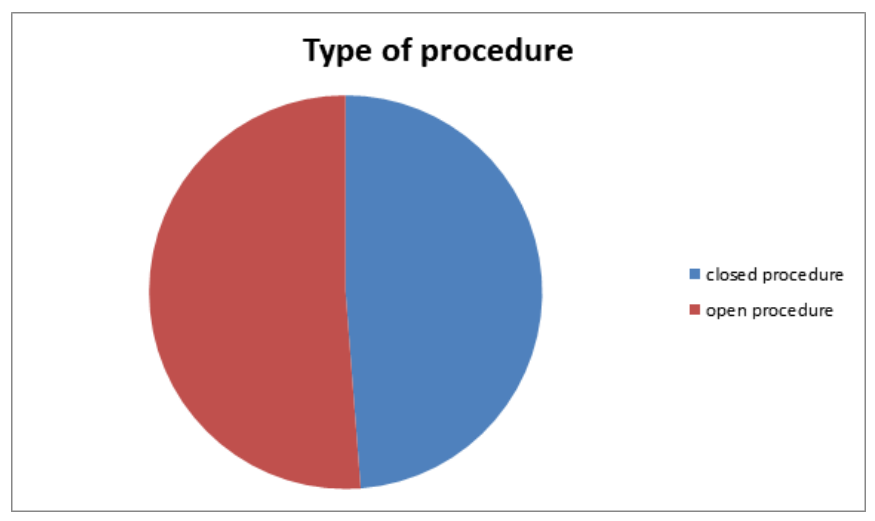

Figure 2: Type of Procedure

Table 3: Mode of presentation (original)

\begin{tabular}{|lll|l|}
\hline Symptoms & $\begin{array}{l}\text { Number } \\
\text { patients }\end{array}$ & of & Percentage \\
\hline Pain only & 65 & $61.46 \%$ \\
\hline $\begin{array}{l}\text { Pain with bleed- } \\
\text { ing per rectum }\end{array}$ & 40 & $38.54 \%$ \\
\hline
\end{tabular}

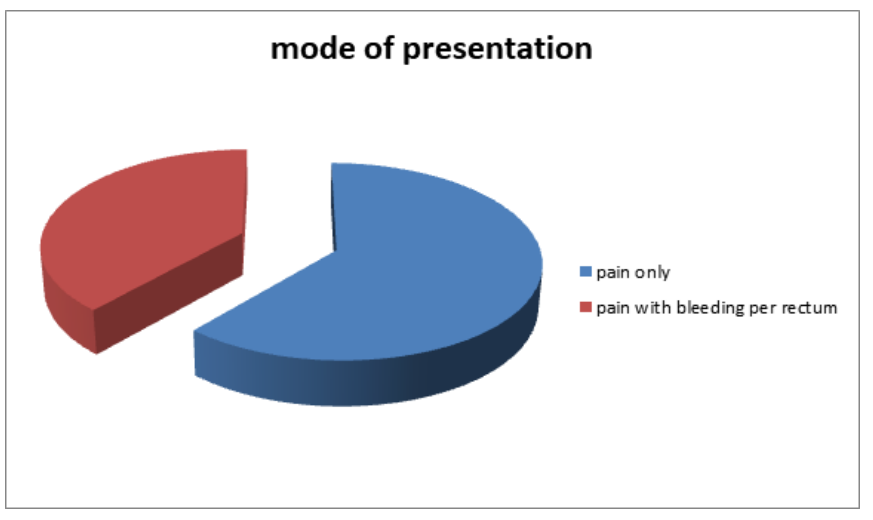

Figure 3: Mode of presentation

\begin{tabular}{|c|c|c|}
\hline Site of fissure & $\begin{array}{l}\text { Number of } \\
\text { patients }\end{array}$ & Percentage \\
\hline $\begin{array}{l}\text { Posterior } \\
\text { fissure }\end{array}$ & 84 & $80 \%$ \\
\hline Anterior fissure & 19 & $18 \%$ \\
\hline Both locations & 2 & $2 \%$ \\
\hline
\end{tabular}

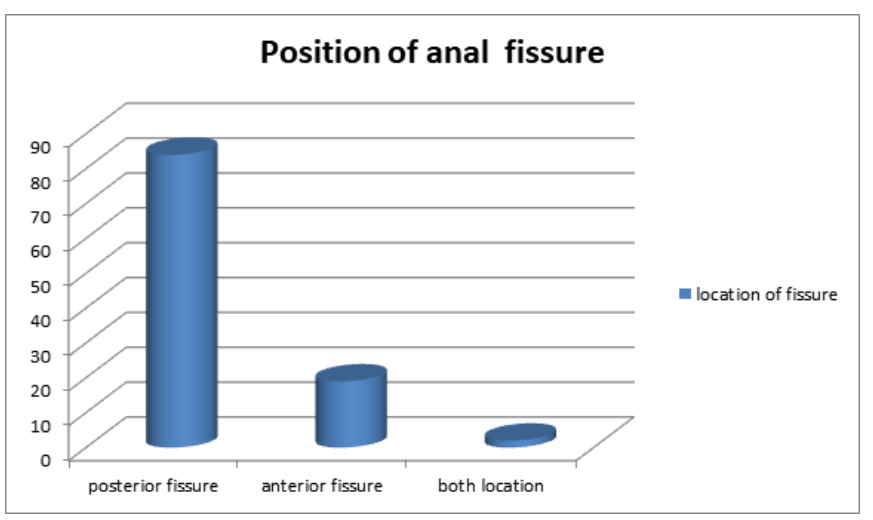

Figure 4: Position of Anal fissure

In group $\mathrm{A}$, patients who underwent closed internal anal sphincterotomy procedure, 40 of 50 patients were free of symptoms on immediate post-operative day. In group B who underwent open internal anal sphincterotomy, 37 of 55patients were free of symptoms on immediate post-operative day.

In both groups, few patients showed complications. 8 patients complained of postoperative pain in group A compared with 20 patients in group B. pain improved by one month in both groups. (chi square statistic is 4.6 and the $P$ value is 0.03 which is significant) 
Bleeding after surgery was found in five patients in group A and one patient in Group B (chi square statistic is 1.9 and $\mathrm{P}$ value is 0.16 which is not significant)

Infection was found in 2 patients in group A compared to 10 patients in group $\mathrm{B}$ (chi square statistic is 3.9 and $\mathrm{P}$ value is 0.04 which is significant)

Mild incontinence to flatus, which was temporary, was found in 3 patients in group A compared with 4 patients in group B (chi square statistic is 0.02 and $\mathrm{P}$ value is 0.89 which is not significant) Recurrence was noticed in 5 patients in group A compared to 3 patients in group B (chi square statistic is 0.25 and $P$ value is 0.6 which is not significant).

\begin{tabular}{|c|c|c|c|}
\hline Complication & Group A & Group B & $\begin{array}{l}\mathrm{P} \text { value based } \\
\text { on chi square } \\
\text { test }\end{array}$ \\
\hline Pain & 8 & 20 & $\begin{array}{l}0.03 \text { (signifi- } \\
\text { cant) }\end{array}$ \\
\hline Bleeding & 5 & 1 & 0.16 \\
\hline Infection & 2 & 10 & $\begin{array}{l}0.04 \quad \text { (signifi- } \\
\text { cant) }\end{array}$ \\
\hline Incontinence & 3 & 4 & 0.89 \\
\hline Recurrence & 5 & 3 & 0.60 \\
\hline
\end{tabular}

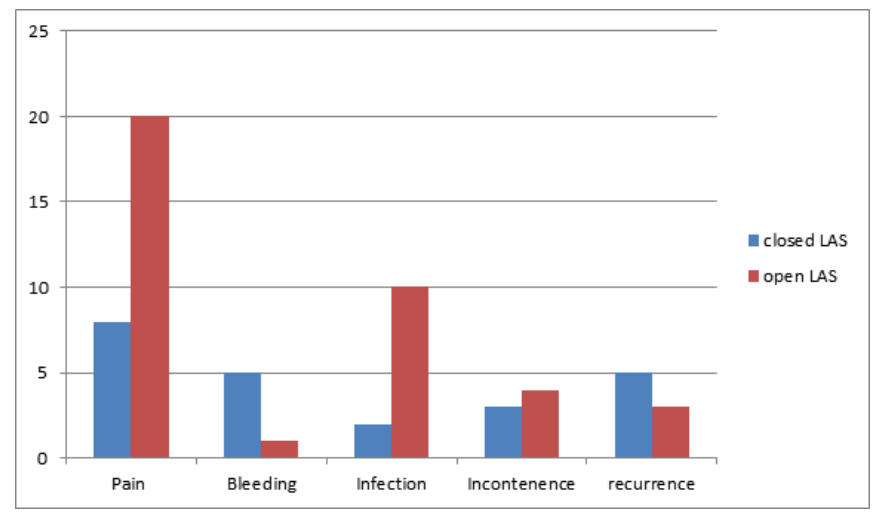

Figure 5: Open Vs Closed LAS

\section{Discussion}

In our study, we have conducted a prospective study in Department of General Surgery, IGMCRI, pondicherry from June 2018 to December 2018 among 105 patients undergoing lateral anal sphincterotomy for chronic fissure in ano (either closed method or open method) and have compared these two methods in terms of postoperative pain, bleeding, infection rates, incontinence, recurrence. ${ }^{[9]}$
According to the observation based on Table 1 \& Figure 1, the peak age incidence of chronic fissure in ANO is observed between $25-35$ years. A total of 32 males and 73 females were considered for study and the male-to-female ratio in this study is $1: 2.3$.

According to Table $2 \&$ Figure 2: 105 cases admitted through surgery outdoor were divided into two groups. In this process 50 cases underwent closed lateral anal sphincterotomy (LAS), 55 cases open LAS.

All the 105 patients underwent surgery under spinal anaesthesia in our Institution.

Table $3 \&$ Figure 3 demonstrate around $62 \%$ patients presented with only pain during defecation and $38 \%$ presented with pain and bleeding per rectum during defecation. This is similar to the observation made byHananel and Gordon. ${ }^{[10]}$

Table 4 \& Figure 4 demonstrates the common site of chronic fissure in ano. In $80 \%$ of cases the fissure was seen in posterior aspect and in $18 \%$ seen in anterior aspect and in $2 \%$ fissure seen both in anterior and posterior. This is similar to the observation made by Gupta et al. ${ }^{\text {[9] }}$

Table $5 \&$ Figure 5 compares post-operative complication in both group of patients. It shows the incidence of post-operative pain and infection is significantly less in group a (closed procedure) compared to group B (open procedure). This is in concordance with the observation made by Hiltunen and Matikainen. ${ }^{[11]}$ Whereas other complications including postoperative bleeding, incontinence and recurrence doesn't shows any significant difference in both groups. Pernikoff et al. have reported that the complication rate is relatively higher in open LAS Kortbeek et al and Ullah and Nadeem also observed that closed sphincterotomy is associated with lesser complications when compared to open method. ${ }^{[12-14]}$

\section{Summary}

105 cases of chronic anal fissure admitted to Department of Surgery, Indira Gandhi Medical College and Hospitals, puducherry during June 2018 to December 2018 were divided into two groups .50 cases underwent closed LAS and 55 cases underwent open LAS. After thorough investigation and preoperative preparation, patients were subjected for surgery.

Post operative pain, bleeding, local infection, incontinence, recurrence were observed keenly and data recorded according to case record form. In our study, the male-to- female ratio was 1: 2.3 with female predominance. The peak age incidence in our study was between 25 - 35 yrs. Most common presentation was pain during defaecation seen in $62 \%$ and the most common location of chronic fissure was posterior or 6 o'clock position seen in $80 \%$.

The incidence of postoperative pain and local infection were significantly lower in closed LAS as compared to open LAS. Other post-operative complications were not significantly 
different among two groups.

\section{Conclusion}

Lateral anal internal sphincterotomy(LAS) is the surgery of choice in patients with chronic fissure in ano. Among the two methods closed LAS is better compared to open LAS as it has lower rate of post operative complications.

\section{References}

1. Gibbons CP, Read NW. Anal hypertonia in fissures: Cause or effect? Br J Surg. 1986;73(6):443-445. Available from: https://dx.doi.org/10.1002/bjs.1800730609.

2. Mcnamara MJ, Percy JP, Fielding IR. A Manometric Study of Anal Fissure Treated by Subcutaneous Lateral Internal Sphincterotomy. Ann Surg. 1990;211(2):235-238. Available from: https://dx.doi.org/10.1097/00000658-199002000-00017.

3. Sajid M, Afzal M. Lateral internal sphincterotomy; outcome and complications. Professional Med J. 2009;16(1):24-28.

4. Vila S, Garcia C, Piscoya A, Rios RDL, Pinto J, Mercada $\mathrm{JH}$, et al. Use of glycerol trinitrate in an ointment for the management of chronic anal fissure at the National Hospital 'Cayetano Heredia. Rev Gastroenterol Peru. 2009;29:33-39.

5. Wiley M, Day P, Rieger N, Stephens J, Moore J. Open vs. Closed Lateral Internal Sphincterotomy for Idiopathic Fissurein-Ano: A Prospective, Randomized, Controlled Trial. Dis Colon Rectum. 2004;47(6):847-852. Available from: https: //dx.doi.org/10.1007/s10350-004-0530-2.

6. Hyman N. Incontinence after lateral internal sphincterotomy: a prospective study and quality of life assessment. Dis Colon Rectum. 2004;47:35-38. Available from: https://doi.org/10. 1007/s10350-003-0002-0.

7. Hasse C, Brune M, Bachmann S, Lorenz W, Rothmund M, Sitter H. Lateral, partial sphincter myotomy as therapy of chronic anal fissure. Long-term outcome of an epidemiological cohort study. Chirug. 2004;75:160-167. Available from: https: //doi.org/10.1007/s00104-003-0758-8.

8. Callion KM, Gardner KR. Progress in the understanding and treatment of chronic anal fissure. Postgrad Med J. 2001;77(914):753-768. Available from: https://dx.doi.org/10. 1136/pmj.77.914.753.

9. Gupta V, Rodrigues G, Prabhu R, Ravi C. Open versus closed lateral internal anal sphincterotomy in the management of chronic anal fissures: A prospective randomized study. Asian J Surg. 2014;37(4):178-183. Available from: https://dx.doi. org/10.1016/j.asjsur.2014.01.009.

10. Hananel N, Gordon PH. Lateral internal sphincterotomy for fissure-in-ano-Revisited. Dis Colon Rectum. 1997;40(5):597-602. Available from: https://dx.doi.org/10. 1007/bf02055386.

11. Hiltunen KM, Matikainen M. Closed lateral subcutaneous sphincterotomy under local anaesthesia in the treatment of chronic anal fissure. Ann Chir Gynaecol. 1991;80:353-359.

12. Pernikoff BJ, Eisenstat TE, Rubin RJ, Oliver GC, Salvati EP. Reappraisal of partial lateral internal sphincterotomy. Dis Colon Rectum. 1994;37(12):1291-1295. Available from: https: //dx.doi.org/10.1007/bf02257799.

13. Kortbeek JB, Langevin JM, Khoo RE, Heine JA. Chronic fissure-in-ano: A randomized study comparing open and subcutaneous lateral internal sphincterotomy. Dis Colon Rectum. 1992;35:835-842. Available from: https://doi.org/10. 1007/BF02047868.

14. Ullah S, Nadeem M. Closed versus open lateral internal sphincterotomy in chronic anal fissure: A comparative study of postoperative complications and results. Pak J Med Res. 2004;43:1-4. Available from: http://dx.doi.org/10.18203/ 2349-2902.isj20170861.

Copyright: (C) the author(s), 2020. It is an open-access article distributed under the terms of the Creative Commons Attribution License (CC BY 4.0), which permits authors to retain ownership of the copyright for their content, and allow anyone to download, reuse, reprint, modify, distribute and/or copy the content as long as the original authors and source are cited.

How to cite this article: Shanmugaiah A, Pandian S. Prospective Randomized Study between Open Vs Closed Lateral Anal Internal Sphincterotomy in Patients with Chronic Fissure in Ano. Acad. J Surg. 2020;3(1):167-171.

DOI: dx.doi.org/10.47008/ajs/2020.3.1.36

Source of Support: Nil, Conflict of Interest: None declared. 